\title{
Watershed Scale Response to Climate Change-Sagehen Creek Basin, California
}

\section{Introduction}

General Circulation Model (GCM) simulations of future climate through 2099 project a wide range of possible scenarios (Intergovernmental Panel on Climate Change, 2007). To determine the sensitivity and potential effect of long-term climate change on the freshwater resources of the United States, the U.S. Geological Survey Global Change study, "An integrated watershed scale response to global change in selected basins across the United States" was started in 2008. The long-term goal of this national study is to provide the foundation for hydrologically based climate-change studies across the nation.

Fourteen basins for which the Precipitation Runoff Modeling System (PRMS) has been calibrated and evaluated were selected as study sites. PRMS is a deterministic, distributedparameter watershed model developed to evaluate the effects of various combinations of precipitation, temperature, and land use on streamflow and general basin hydrology. Output from five GCMs and four emission scenarios were used to develop an ensemble of climate-change scenarios for each basin. These ensembles were simulated with the corresponding PRMS model. This fact sheet summarizes the hydrologic effect and sensitivity of the PRMS simulations to climate change for Sagehen Creek Basin near Truckee, California (U.S. Geological Survey streamflow-gaging station 10343500; fig. 1) presented in the project summary report (Markstrom and others, 2012) and a journal article (Hay and others, 2011).

\section{Study Area}

Sagehen Creek, a tributary to the Truckee River in California, is located on the east slope of the northern Sierra Nevada. Sagehen Creek drains an area of 27 square kilometers $\left(\mathrm{km}^{2}\right)$ and ranges in elevation from approximately 1,900 to 2,600 meters. Geology of the basin consists of granodiorite bedrock overlain by Tertiary andesitic volcanics, which are overlain by till and alluvium composed of granodiorite and andesite clasts (Rademacher and others, 2005).

Average annual precipitation ranges from 86 centimeters $(\mathrm{cm})$ at elevations less than 2,134 meters $(\mathrm{m})$ to a maximum of $117 \mathrm{~cm}$ at elevations of $2,575 \mathrm{~m}$. Generally, air temperature decreases as elevation increases; however, temperature inversions are common. Mean annual temperature near Sagehen Creek from 1980 to 2002 was $4{ }^{\circ} \mathrm{C}$ at an elevation of 2,545 m (Markstrom and others, 2008). Sagehen Creek is a snowmelt dominated basin, with peak flows in May and minimum flows in September. Daily mean streamflow values were obtained for Sagehen Creek at the streamflow-gaging station 10343500 near the outlet of the basin (fig. 1). The streamflow-gaging station is part of the U.S. Geological Survey's hydrologic benchmark network, established to provide long-term measurements of streamflow and water quality that are minimally affected by human activities (Leopold, 1962).

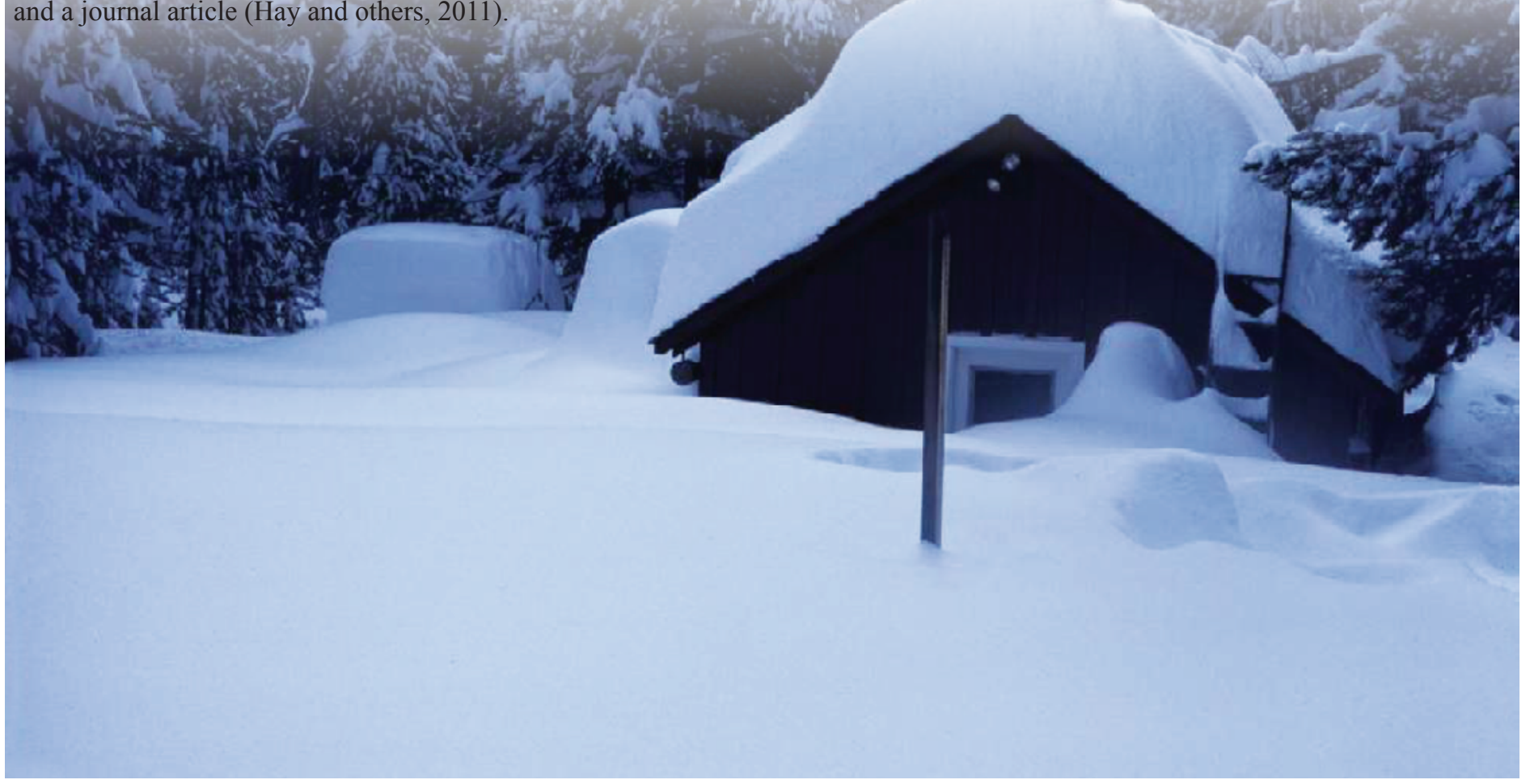



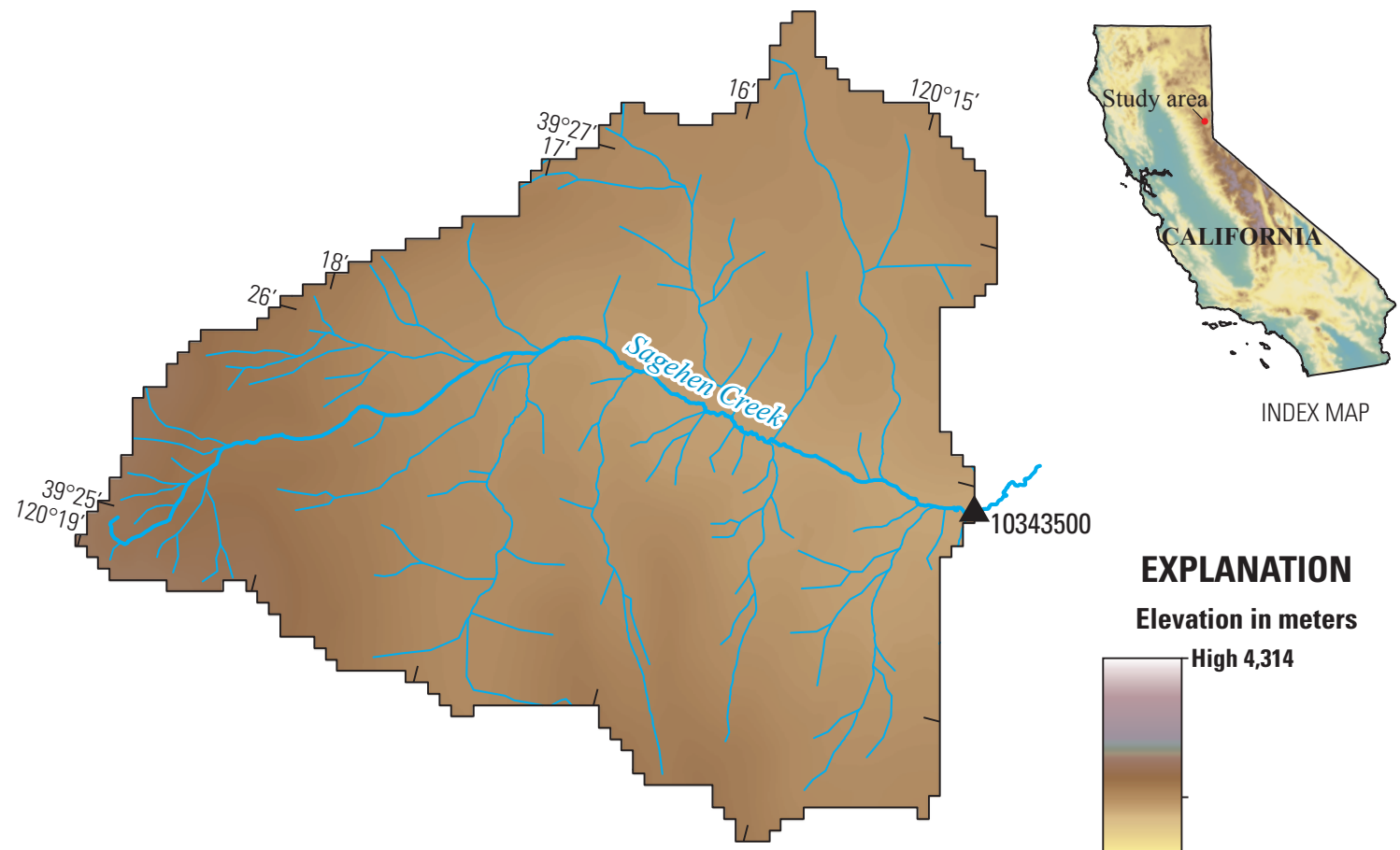

INDEX MAP

Base from U.S. Geological Survey digital data, 2011 1:100,000

Albers Equal-Area Conic projection

Standard parallels $29^{\circ} 30^{\prime} \mathrm{N}$ and $45^{\circ} 30^{\prime} \mathrm{N}$

Central meridian $96^{\circ} 00^{\prime} \mathrm{W}$, Latitude of origin $23^{\circ} 00^{\prime} \mathrm{N}$

Horizontal coordinate information is referenced to the World Geodetic System of 1984 (WGS 84)

U.S. Geological Survey streamflowgaging station and identifier

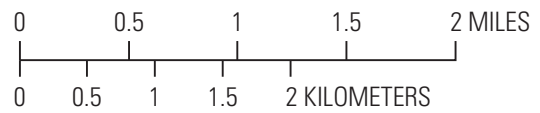

Figure 1. Precipitation Runoff Modeling System study locations, Sagehen Creek Basin, California, and location of U.S. Geological Survey streamflow-gaging station 10343500 with a drainage area of 27 square kilometers and elevation range from 1,941 to 2,589 meters.

\section{General Circulation Models}

Given the uncertainty in climate modeling, it is desirable to use more than one GCM to obtain a range of potential future climatic conditions. Monthly precipitation and temperature output from five GCMs were processed (table 1).

Table 1. General Circulation Model (GCM) projections used in this study.

\begin{tabular}{ll}
\hline \multicolumn{1}{c}{ GCM } & \multicolumn{1}{c}{ Center and country of origin } \\
\hline BCC-BCM2.0 & Bjerknes Centre for Climate Research, Norway \\
CSIRO-Mk3.0 & Australia's Commonwealth Scientific and Industrial Research Organization, Australia \\
CSIRO-Mk3.5 & Australia's Commonwealth Scientific and Industrial Research Organization, Australia \\
INM-CM3.0 & Institute for Numerical Mathematics, Russia \\
MIROC3.2 & National Institute for Environmental Studies, Japan \\
\hline
\end{tabular}


The GCM outputs were obtained from the World Climate Research Programme's Coupled Model Intercomparison Project phase 3 multi-model dataset archive, which was referenced in the Intergovernmental Panel on Climate Change Fourth Assessment Special Report on Emission scenarios (Intergovernmental Panel on Climate Change, 2007). For each GCM, one current (water years 1988-1999) and three future emission scenarios were used and are described in table 2.

Table 2. Climate-change emission scenarios simulated by the General Circulation Models in this study.

\begin{tabular}{ll}
\hline \multicolumn{1}{c}{ Emission scenario } & \multicolumn{1}{c}{ Description/assumptions } \\
\hline 20C3M & $\begin{array}{l}\text { 20th century climate used to determine baseline (1989-1999) conditions } \\
\text { Rapid economic growth, a global population that peaks in mid-21st century and rapid introduction of new and } \\
\text { m1B }\end{array}$ \\
m1 & $\begin{array}{c}\text { Convergent world, with the same global population as Emission scenario A1B, but with more rapid changes in } \\
\text { economic structures toward a service and information economy that is more ecologically friendly } \\
\text { A2 }\end{array}$ \\
\hline
\end{tabular}

Climate-change fields were derived by calculating the change in climate from current (water years 1988-1999) to future conditions simulated by each GCM. The 20C3M simulation for water years 1988-1999 was used to represent current climatic conditions. This 12-year period of record was chosen based on the overlap of the available historical records from the 14 basins included in the national study. Climate change fields (percentage changes in precipitation and degree changes in temperature) were computed for 12-year moving window periods (from 2001-2099) using the 20C3M (1988-1999) and the A1B, B1, and A2 emission scenarios. A 12-year moving window, starting in 2001 and ending in 2099, results in 1,320 future scenarios $[(88,12$-year climatologies, 1 per year starting with 2001-2012 and ending with 2088-2099) x (3 emission scenarios) x (5 GCMs)].

Climate-change scenarios were generated for PRMS by modifying PRMS precipitation and temperature inputs with the mean monthly climate change fields derived from the GCMs, resulting in 1,320 PRMS-input files. Table 3 shows the change (slope) and adjusted $\mathrm{R}^{2}$ (adjR2) for the least squares fit to the trend line for selected output variables from the PRMS projections. The slope indicates the change in the selected variable by year. The adjusted $R^{2}$ value gives an indication of the variability in the central tendency of the trend line.

Figure 2 shows a summary of the projected range in 11-year moving mean daily values of maximum temperature (fig. $2 A$ ), minimum temperature (fig. $2 B$ ), and precipitation (fig. $2 C$ ) by emission scenario. The first year of each 12-year simulation was used as PRMS initialization and is not included in the results. The three solid-colored lines indicate the 11-year moving mean values (x-axis indicates center of 11-year window) for the three future emission scenarios (central tendency of the five GCMs for each emission scenario). The projected range shown for each emission scenario indicates the range of potential future climatic conditions simulated by the five GCMs. All GCM simulations project steady increases in maximum and minimum temperature (table 3), with uncertainties associated with these GCM projections increasing with time. Both maximum and minimum temperatures show the smallest projected changes for the B1 emission scenario. Projected mean annual precipitation for the Sagehen Creek Basin is highly variable, with a slight tendency towards an overall increase in precipitation by the end of the 21 st century for the A1B emission scenario (table 3 ). The wide range in the precipitation projections indicates a large amount of uncertainty.

\section{Results}

PRMS simulates spatially distributed streamflow, components of flow (surface, subsurface, and groundwater), snowpack conditions, and many other hydrologic components of interest. Figure 3 shows a summary of PRMS-simulated basin mean values of streamflow, and corresponding components of flow by emission scenario. The central tendency of the five GCMs for each of the three future emission scenarios (indicated by the solid-colored lines) shows the same oscillation seen in the precipitation output (fig. $2 C$ ), but with no discernible overall trend in mean annual streamflow (fig. $3 A$ and table 3 ). The components of flow indicate that the subsurface flow component (fig. $3 C$ ) has the most influence on the corresponding changes seen in total streamflow (fig. $3 A$ ). The central tendency of the PRMS simulations using the GCM scenarios project a significant positive trend in mean annual surface runoff (fig. $3 B$ ) for the A1B and B1 emission scenarios (table 3). The subsurface and groundwater flow projections are similar to the streamflow projections of increases and decreases with no discernible overall trends (figs. $3 C, 3 D$, and table 3 ).

Projections in simulated evapotranspiration can be examined on a monthly basis (fig. 4). The red lines in figure 4 show PRMS-simulated mean monthly baseline conditions (1989-1999) for evapotranspiration. The boxplots represent the range in the mean monthly projections of the five GCMs and three future scenarios for 2030 (green, 2025-2035), 2060 (tan, 2055-2065) and 2090 (blue, 2085-2095). Results indicate by the end of the 21 st century there will be increases in evapotranspiration from December through May, followed by decreases from July through September. 

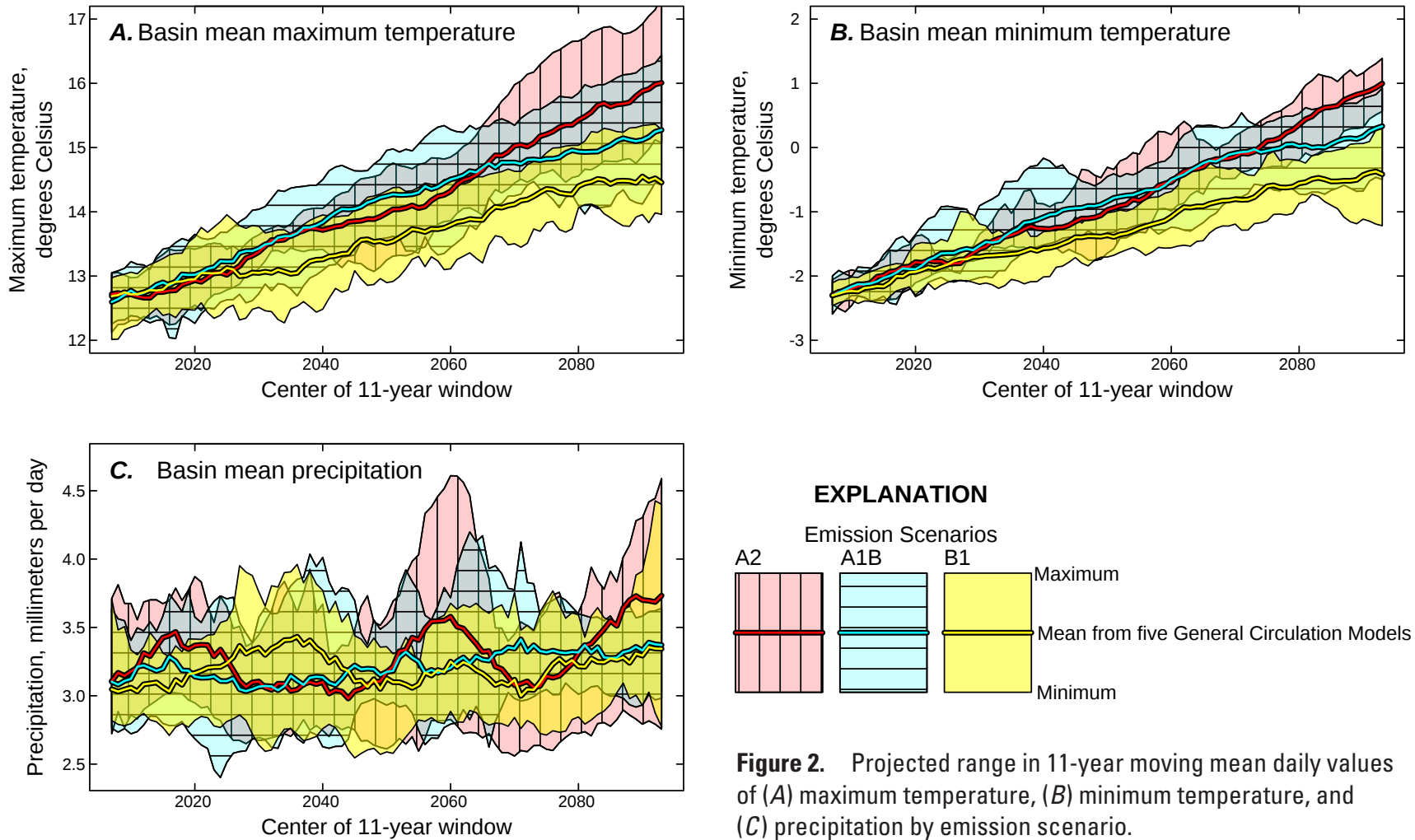

EXPLANATION

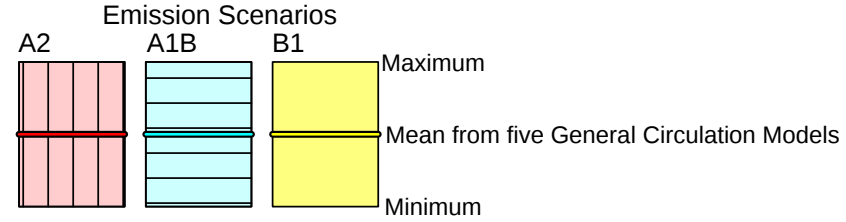

Figure 2. Projected range in 11-year moving mean daily values of $(A)$ maximum temperature, $(B)$ minimum temperature, and (C) precipitation by emission scenario.

Table 3. Projected change by year (slope) and adjusted $R^{2}$ (adjR2) based on the central tendencies of the five General Circulation Models for the three carbon emission scenarios for selected Precipitation Runoff Modeling System (PRMS)output variables.

[Blue indicates a significant negative trend and yellow indicates a significant positive trend $(\mathrm{p}<0.05)$ accounting for lag-1 autocorrelation]

\begin{tabular}{|c|c|c|c|c|c|c|}
\hline \multirow{2}{*}{ PRMS output variable } & \multicolumn{2}{|c|}{$\begin{array}{c}\text { Emission scenario } \\
\text { A1B }\end{array}$} & \multicolumn{2}{|c|}{$\begin{array}{c}\text { Emission scenario } \\
\text { A2 } \\
\end{array}$} & \multicolumn{2}{|c|}{$\begin{array}{c}\text { Emission scenario } \\
\text { B1 }\end{array}$} \\
\hline & slope & $\operatorname{adjR2}$ & slope & $\operatorname{adjR2}$ & slope & $\operatorname{adjR2}$ \\
\hline Maximum temperature in degrees Celsius & 0.031 & 0.98 & 0.040 & 0.98 & 0.024 & 0.98 \\
\hline Minimum temperature in degrees Celsius & 0.031 & 0.99 & 0.037 & 0.98 & 0.023 & 0.99 \\
\hline Precipitation in millimeters per day & 0.0031 & 0.60 & 0.0033 & 0.16 & 0.0009 & 0.03 \\
\hline Evapotranspiration in millimeters per day & 0.0020 & 0.94 & 0.0021 & 0.84 & 0.0013 & 0.82 \\
\hline Streamflow in cubic meters per second & 0.0004 & 0.23 & 0.0005 & 0.04 & -0.0001 & -0.01 \\
\hline Surface runoff in cubic meters per second & 0.00027 & 0.90 & 0.00044 & 0.66 & 0.00022 & 0.75 \\
\hline Subsurface flow in cubic meters per second & 0.00012 & 0.04 & 0.00007 & -0.01 & -0.00020 & 0.05 \\
\hline Groundwater flow in cubic meters per second & 0.00002 & 0.01 & -0.00003 & -0.01 & -0.00008 & 0.10 \\
\hline Snowpack water equivalent in millimeters per day & -0.79 & 0.88 & -1.04 & 0.77 & -0.79 & 0.80 \\
\hline
\end{tabular}

Intermediate states of interest, produced by PRMS, are summarized in Markstrom and others (2010). Analysis of these intermediate states may indicate areas of the water balance most susceptible to changes in climate. For example, figure 5 shows the change in simulated snowpack storage, expressed in liquid water equivalent. The central tendencies for the A1B and B1 emission scenarios projects an overall negative trend in mean annual snowpack storage (table 3), while the snowmelt projections (not shown) indicate an earlier melt season and more rain falling on the snowpack (not shown) in the Sagehen Creek Basin (Markstrom and others, 2011). Note that the oscillations in the precipitation, which were mentioned earlier, are also observed in the snowpack storage. The precipitation and the increasing temperatures affect the snowpack storage. 

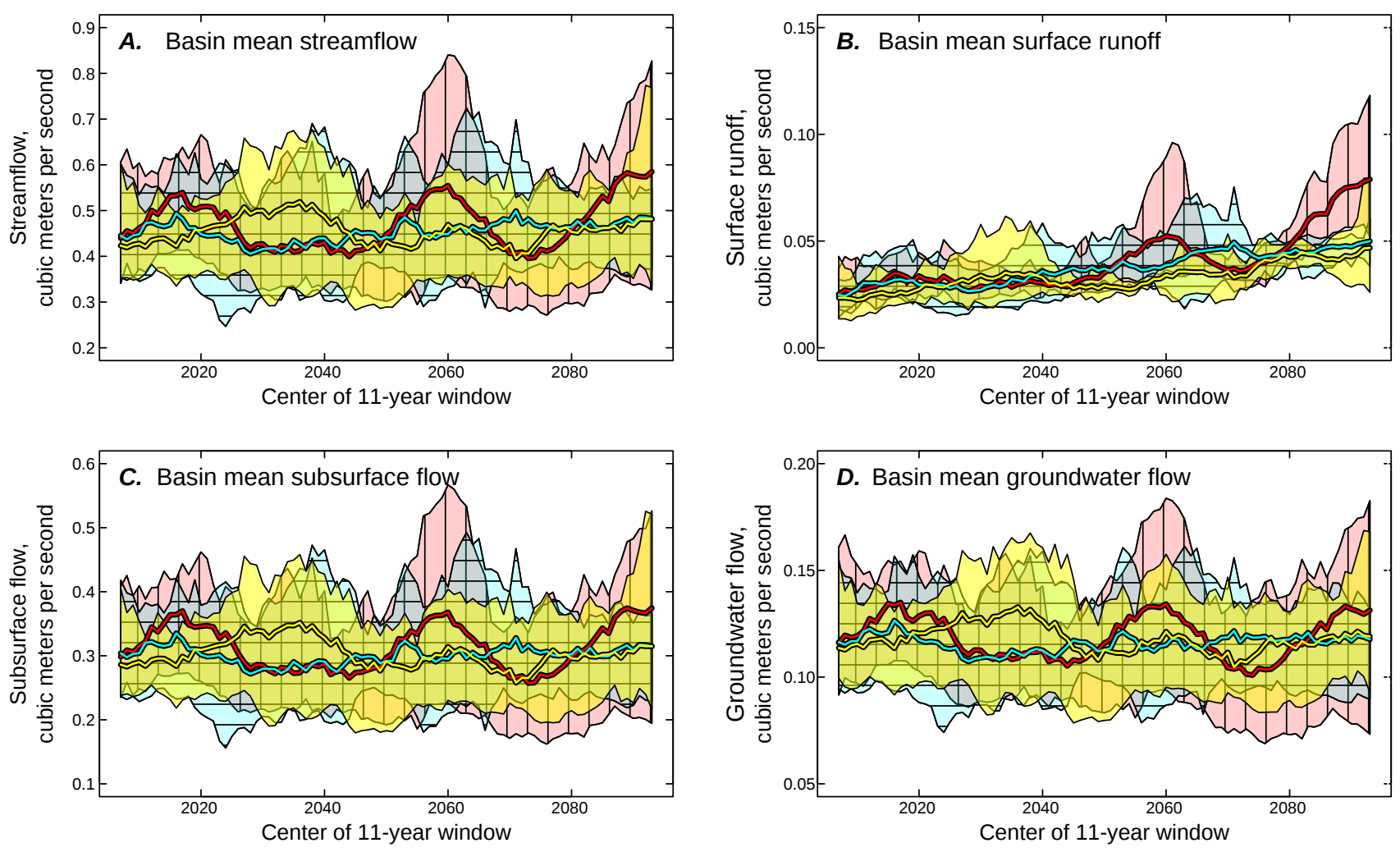

Figure 3. Projected range in 11-year moving mean daily values of $(A)$ streamflow, $(B)$ surface runoff, $(C)$ subsurface flow, and $(D)$ groundwater flow by emission scenario.
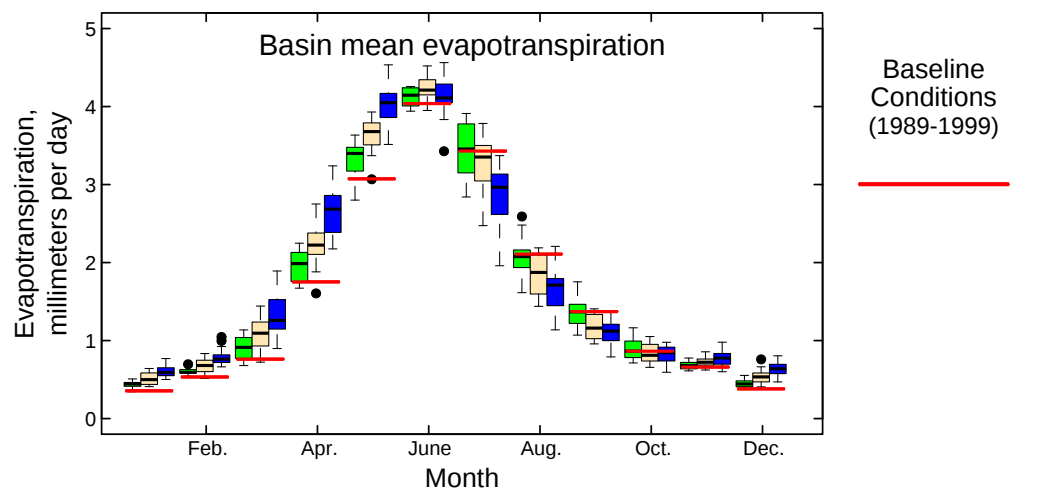

\section{EXPLANATION}

$\begin{array}{ccc}2030 & 2060 & 2090 \\ (2025-2035) & (2055-2065) & (2085-2095)\end{array}$

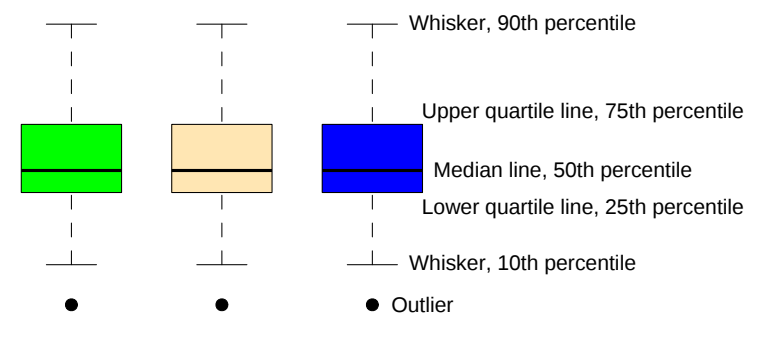

Figure 4. Mean daily evapotranspiration values by month for baseline conditions and projected range $(2030,2060$, and 2090$)$ using the five General Circulation Models and three emission scenarios.

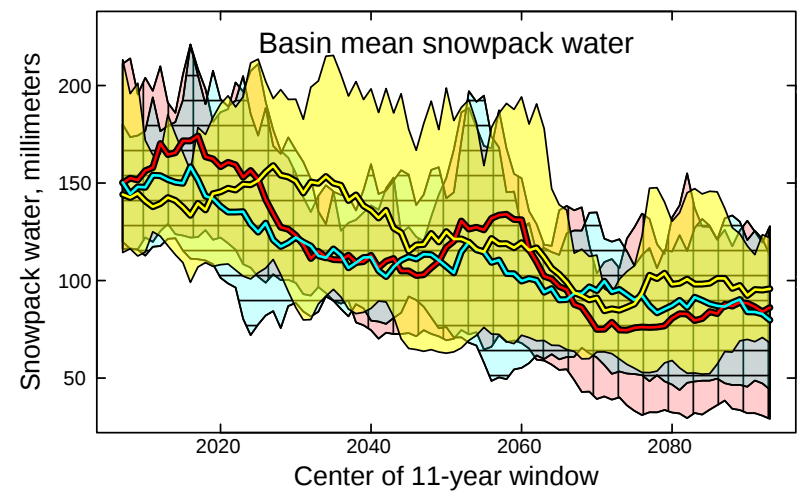

\section{EXPLANATION}

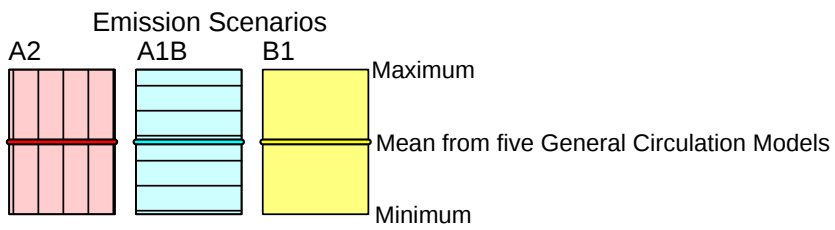

Figure 5. Projected range in 11-year moving mean daily values of snowpack water equivalent by emission scenario. 


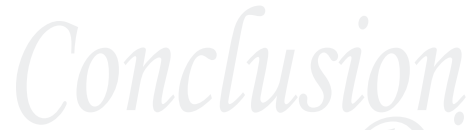

\section{Conclusion and Discussion}

In northern Nevada and central California increased development, combined with severe droughts, have resulted in shortages and restrictions on limited surface-water supplies. The broader-scale effect of climate change on the flow regime and water-balance components of Sagehen Creek indicates a shift in timing of peak streamflow from May to April with no overall discernible trend in annual flows. The uncertainties associated with the projections are large. These results did not consider many of the important feedback mechanisms which act between the land surface and the atmosphere.

The combined effects of climate change and urbanization in the vicinity of Sagehen Creek may alter both the quantity and timing of streamflow and have the potential to change the conditions that support biological diversity in aquatic communities. The scientific techniques described in the fact sheet can be augmented with other techniques in developing the science needed to address these complicated dynamics.

\section{Selected References}

Hay, L.E., Markstrom, S.L., and Ward-Garrison, C.D., 2011, Watershed-scale response to climate change through the twenty-first century for selected basins across the United States, Earth Interactions, v. 15, 37 p.

Intergovernmental Panel on Climate Change, 2007, Summary for policymakers, in Climate change 2007-The physical science basis, Contributions of Working Group 1 to the Fourth Assessment Report of the Intergovernmental Panel on Climate Change: Cambridge and New York, Cambridge University Press, $18 \mathrm{p}$.

Leopold, L.B., 1962, A national network of hydrologic benchmarks: U.S. Geological Survey Circular 460-B, 4 p.

Markstrom, S.L., Hay, L.E., Ward-Garrison, C.D., Risley, J.C., Battaglin, W.A., Bjerklie, D.M., Chase, K.J., Christiansen, D.E., Dudley, R.W., Hunt, R.J., Koczot, K.M., Mastin, M.C., Regan, R.S., Viger, R.J., Vining, K.C., and Walker, J.F., 2012, An integrated watershed scale response to climate change for selected basins across the United States: U.S. Geological Survey Scientific Investigations Report 2011-5077, 142 p.

Markstrom, S.L., Niswonger, R.G., Regan, R.S., Prudic, D.E., and Barlow, P.M., 2008, GSFLOW-Coupled ground-water and surface- water flow model based on the integration of the Precipitation-Runoff Modeling System (PRMS) and the modular ground-water flow model (MODFLOW-2005): U.S. Geological Survey Techniques and Methods 6-D1, 240 p.

Rademacher, L.K., Clark, J.F., Clow, D.W., and Hudson, G.B., 2005 , Old groundwater influence on stream hydrochemistry and catchment response times in a small Sierra Nevada catchment: Sagehen Creek, California: Water Resources Research, v. 41, no. W02004, doi: 10.1029/2003WR002805, 10 p.

By Steven L. Markstrom, Lauren E. Hay and R. Steven Regan

For more information visit the following Web sites:

http://wwwbrr.cr.usgs.gov/projects/SW_MoWS/

http://nv.water.usgs.gov/

http://www.usgs.gov/climate_landuse/ 